\title{
DIVERSITY OF THE CLOSED-NESTED HONEY BEES (APIDAE: $A P I S$ SPP.) AND THE TRADITIONAL HONEY COLLECTING AND BEEKEEPING IN FOUR ISLANDS OF INDONESIA
}

\author{
Sih Kahono*1, Djunijanti Peggie ${ }^{1}$, and Eko Sulistyadi ${ }^{1}$ \\ ${ }^{1}$ Museum Zoologicum Bogoriense, Research Center for Biology, National Research \\ and Innovation Agency, Jl. Raya Jakarta-Bogor Km. 46, Cibinong, Bogor 16911, Indonesia \\ *Corresponding author: sihkahono@gmail.com; sihk001@brin.go.id
}

Received: 30 November 2021; Accepted: 14 December 2021; Published: 30 December 2021

\begin{abstract}
The closed-nested honey bees are an important group that has been successfully bred traditionally and in a modern way. The traditional honey beekeeping practices are still favorable by local people living near natural habitats. Many rural areas in Indonesia are well known as producers of honey from the traditional honey collecting and traditional honey beekeeping of the closed-nested honey bees. However, there is limited information on the diversity of the honey bees that had supported the honey productions and their traditional honey beekeeping. This research was to provide an overview of the diversity of the honey bee species that are used in the wild honey collecting and their traditional honey beekeeping in four selected study sites in the islands of Java, Bawean, Kalimantan, and Peleng. We recorded three species of closed-nested native honey bees in the traditional honey collecting and traditional honey beekeeping, namely Apis cerana, A. koschevnikovi, and A. nigrocincta. We observed that traditional beekeeping of $A$. cerana was carried out in Tasikmalaya and Bawean Island, and that of A. cerana and A. koschevnikovi were carried out in Kayan Hilir. On Peleng Island, people do not do beekeeping but collect honey directly from the forest. Honey collecting and beekeeping practices are related to changes in the seasons of the flowering period in their habitats. The knowledge of the flowering period is needed to know the seasonal movement of honey bees from forest to village and vice versa.
\end{abstract}

Key words: Apis cerana, A. koschevnikovi, A. nigrocincta, Indonesia, traditional honey collecting and beekeeping

\section{INTRODUCTION}

Indonesia has the highest diversity of honey bees (Apis spp.) in the world (Hadisoesilo, 2001; Engel, 2012; Kahono et al., 2018). Except for some of the endemic subspecies in other countries, almost all species in the world occur in Indonesia, and most of them are island endemic (Otis, 1991; Hadisoesilo, 2001; Kahono, 2018).

There are two kinds of bee nesting types, single comb attached under branches or other hard substances at the open and multi combs hanging in many kinds of cavities (Otis, 1991; Hadisoesilo, 1997, 2001; Kahono et al., 2018). Three species of Apis nested in the cavities of the trees, rocks, and parts of buildings are Apis nigrocincta, A. koschevnikovi, and A. cerana. Apis koschevnikovi is endemic to Sumatra and Borneo, and A. nigrocincta is endemic to Wallacean region. Apis cerana was originally distributed in the eastern part of the Wallacean line, however, it is recently spread across the country (Hadisoesilo \& Otis, 1996; Hadisoesilo et al., 1999; Kahono, 2018; Kahono et al., 2018). 
The open-nested honey bees have never been successfully kept in a hive. Only some practices to attract incoming immigrant colonies of $A$. dorsata have been successfully developed in Indonesia (e.g., Hamidi, 2001; Purba, 2001a, b; Hadisoesilo \& Kuntadi, 2007; Mikael et al., 2015; Jack et al., 2019; Jamiat et al., 2019). The successful practices of attracting colonies of $A$. dorsata have been the local identities (Hadisoesilo \& Kuntadi, 2007; Gratzer et al., 2019; Kahono et al., recent data). The closed-nested or cavity-nested honey bees are the honey bee's species that live in natural hollows and human-made things such as parts of buildings. These honey bees are able to be bred in the traditional beekeeping of manmade hives, boxes, and natural tree trunk hollows. Since the introduction of the European framed honey bee, A. mellifera in 1985 to Java, the traditional honey beekeeping in some locations has been gradually changed to the framed modern style (Mashudi et al., 1998; Kahono et al., 2018). The framed modern honey beekeeping requires extra time, funds, and human effort. The introduction of the framed modern styles to the people of Nanggewer village, Pagerageung, Tasikmalaya (West Java), and Peleng Island (West Sulawesi) was not successful. Local people in both localities preferred to continue their traditional activities to collect the honey directly from the forest and to conduct traditional honey beekeeping (Kahono et al., recent data).

Traditional honey collecting is honey collecting from forests or the wild surroundings that are especially done by native inhabitants or indigenous tribes living in surrounding forests. It involved collecting the honey from cavities of the trees, limestones, undergrounds, and parts of buildings, with traditionally-made gears like man-made baskets, smoke torches, and sometimes with prayer or mantra. Traditional honey beekeeping (or traditional apiculture) is the keeping and maintenance of the honey bee colonies in traditional methods that have been carried out from generation to generation by local honey beekeepers (Onwumere et al., 2012; Sharma et al., 2014; Yilmaz, 2016). Some islands and rural areas are well known as producers of honey, however, there is limited information on the diversity of the honey bees producing the honey and the kind of traditional beekeeping practices that they have conducted.

The traditional honey collecting and beekeeping practices involve the knowledge on how to manage the bees in a local environment, which needs an awareness of local communities to the honey bees, its models, and the condition of its environments. These traditional practices may disappear if they are not passed on to the young generation. Serious habitat change, less suitable food resources, and awareness of local communities are factors to be considered. The study of traditional honey collecting and traditional honey beekeeping of close-nested honey bee species that show seasonal colony movement among two different ecosystem conditions 
has not been conducted yet. These data might be important to understand how to utilize them sustainably. The primary contribution of this paper is to provide an overview of the traditional close-nested honey collecting and beekeeping in the case of four different islands in Indonesia, namely Java, Bawean, Kalimantan, and Peleng.

\section{MATERIALS AND METHODS}

The study was conducted at four different locations and times: (1) in Nanggewer village, Pagerageung, Tasikmalaya, West Java in September 2015; (2) in Teluk Jati village, Tambak, Bawean Island, Gresik, East Java in May 2017; (3) in Data Dian village, Kayan Hilir, Malinau (North Kalimantan) in November 2014, and (4) in Alul village, Bulagi and Lemeleme Darat village, Buko, Banggai Kepulauan (Central Sulawesi) on 25 June-14 July 2019 (Fig. 1). Hereafter, we use the names of Tasikmalaya, Bawean Island, Kayan Hilir, and Peleng Island for further narrations. The type of villages that were used for the research is located surrounding the forests or wild environments and the people living in the villages were mainly native people. In the study sites of Tasikmalaya, Bawean Island, Kayan Hilir, and Peleng Island live Sundanese, Maduranese, Dayaknese, and Tolakinese tribes, respectively. We conducted research on the three main targets: the diversity of closed-nested honey bees, the traditional activities on the collection of honey in the forest or the wild, and

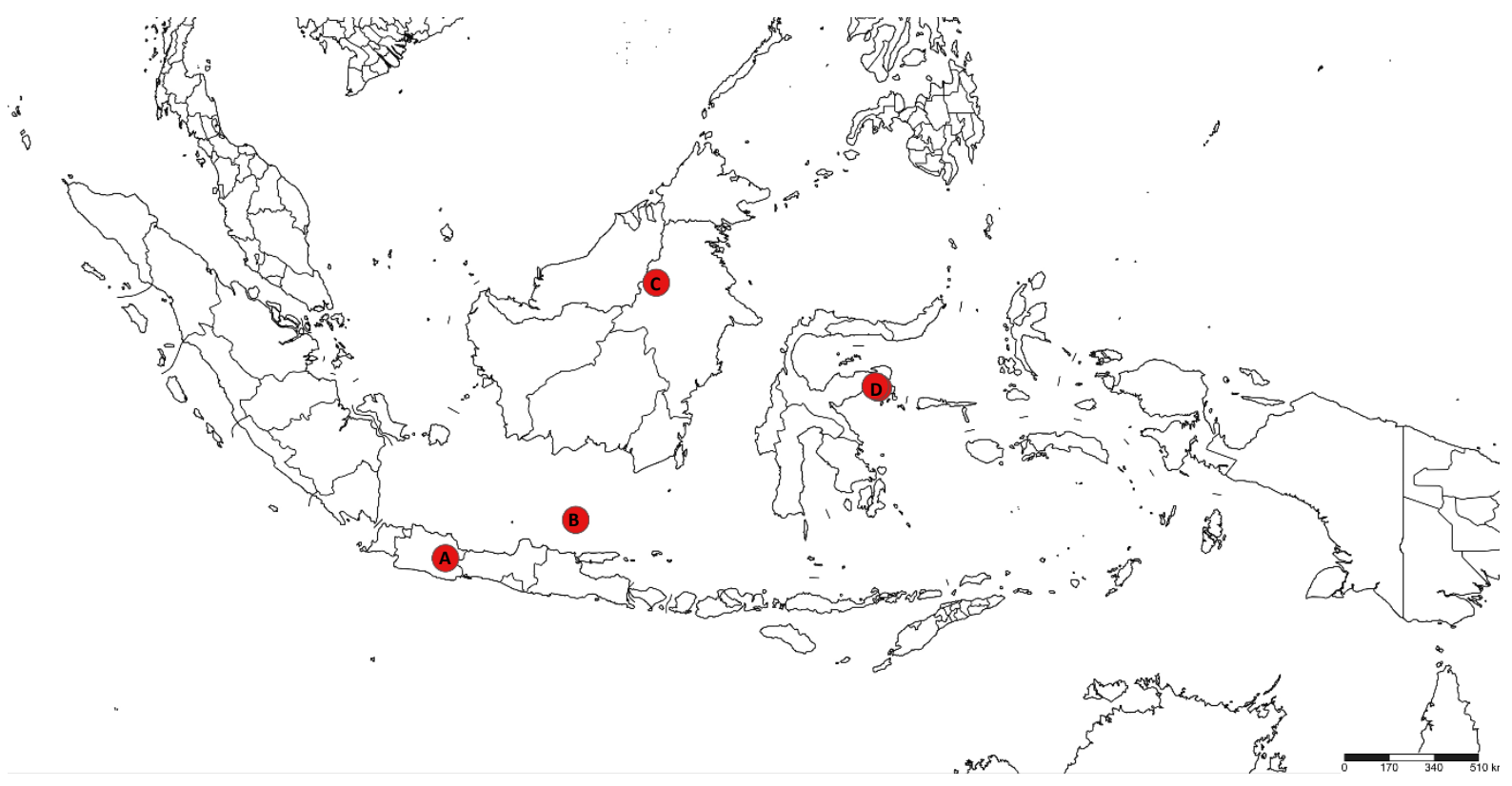

Figure 1. A map of the study sites: (A) Nanggewer Village, Pagerageung District, Tasikmalaya (West Java); (B) Teluk Jati Village, Tambak District (Bawean Island), Gresik (East Java) Regency; (C) Data Dian Village, Kayan Hilir District, Malinau Regency (North Kalimantan); (D) Alul Village, Bulagi District and Leme-leme Darat village, District Buko, Banggai Kepulauan Regency (Central Sulawesi). 
traditional honey beekeeping. To obtain data on the honey bee diversity, specimens were collected at the close-nested honey bee colonies from each locality and the identification was done at the Laboratory of Entomology, Museum Zoologicum Bogoriense.

General information on both traditional honey collecting and honey beekeeping was gathered from the local government, local honey sellers, and local non-government organizations (NGOs). Descriptive qualitative describing the research by the selection of informants by snowball sampling technique (Naderifar, 2017) by determining the key informants to determine other informants who also know the local wisdom of the community such as honey collectors, honey beekeepers, and elderly people who know the history of their own traditional honey beekeeping and knowledge related to the ecology of the honey bee, climate, and phenology.

\section{RESULTS}

\section{Diversity}

All three Indonesian close-nested honey bees were recorded in this study: A. cerana, $A$. koschevnikovi, and A. nigrocincta (Table 1). Apis cerana was found in all locations, while $A$. koschevnikovi was only found in Kayan Hilir, and A. nigrocincta was only in Peleng Island with a low-frequency number of colonies. These three species can be distinguished from the body appearances directly by normal eyes without magnifications. Compared to $A$. cerana, the body color and size of $A$. koschevnikovi is a bit reddish and larger, while A. nigrocincta is a bit yellowish but similar in body sizes. All three belong to a group of multi-layers combs honey bee.

Table 1. Diversity of the close-nested honey bees in the four study sites

\begin{tabular}{lcccc}
\hline \multicolumn{1}{c}{ Species } & Bawean Island & Tasikmalaya & Peleng Island & Kayan Hilir \\
\hline Apis cerana & $\sqrt{ }$ & $\sqrt{ }$ & $\sqrt{ }$ & $\sqrt{ }$ \\
Apis koschevnikovi & - & - & - & $\sqrt{ }$ \\
Apis nigrocincta & - & - & $\sqrt{ }$ \\
\hline
\end{tabular}

All of these species were subject to traditional honey collecting and traditional honey beekeeping. The traditional honey collecting and the beekeeping of A cerana were conducted by local people of the whole study sites of Tasikmalaya, Kayan Hilir, Bawean Island, and Peleng Island, while A. koschevnikovi and the honey collecting of A. nigrocincta were conducted only in Kayan Hilir and Peleng Island, respectively. 


\section{The Traditional Honey Bee Collection}

These activities include collecting honey and parental colonies from the wild colonies, collecting honey and brood for food from the wild colonies, collecting parental colonies by inducement, and allowing wild colonies to move naturally to the urban area (Table 2).

The traditional honey collecting and the honey beekeeping practices in all study sites were usually not the main jobs but seasonal work besides their main job as farmers and animal breeders. In the period of honey collecting time, more people took more time to conduct the traditional honey collecting and honey beekeeping. People conducted the honey collecting in the wild only in one day, alone or sometimes accompanied by a younger family member. In Tasikmalaya and Bawean, the local honey collectors entered the forest or the wild surroundings to collect both honey and the broods in the combs for food of only one species, A. cerana. The same activity was also done to the species of $A$. cerana and $A$. koschevnikovi in Kayan Hilir and to the species of $A$. cerana and A. nigrocincta in Peleng Island. In Tasikmalaya, Bawean Island, and Kayan Hilir, the people who first discovered the honey bee nest was the owner and could collect the honey directly from the nest. In Peleng Island, people who first discovered the nest would make signs to the honey bee colonies to indicate ownership of the nest of the honey bee by bark incisions (Fig. 2), sometimes twigs tipped at the nest, ties, paint, or other marks. Those marks indicated that the colony belonged to the person, and others are prohibited from taking the honey.

Table 2. Main activities of the honey collecting and the traditional honey beekeeping

\begin{tabular}{|c|c|c|c|c|}
\hline Activity & $\begin{array}{l}\text { Bawean Island } \\
(\text { A. cerana })\end{array}$ & $\begin{array}{c}\text { Tasikmalaya } \\
(\text { A. cerana })\end{array}$ & $\begin{array}{c}\text { Peleng Island } \\
\text { (A. cerana \& } \\
\text { A. nigrocincta) }\end{array}$ & $\begin{array}{c}\text { Kayan Hilir } \\
\text { (A. cerana \& } \\
\text { A. } \text { koschevnikovi) }\end{array}$ \\
\hline $\begin{array}{l}\text { Collect honey and parental } \\
\text { colonies from the wild colonies }\end{array}$ & $\sqrt{ }$ & $\sqrt{ }$ & - & $\sqrt{ }$ \\
\hline $\begin{array}{l}\text { Collect honey and brood for } \\
\text { food from the wild colonies }\end{array}$ & $\sqrt{ }$ & $\sqrt{ }$ & $\sqrt{ }$ & $\sqrt{ }$ \\
\hline $\begin{array}{l}\text { Collect parental colonies by } \\
\text { inducement }\end{array}$ & $\begin{array}{l}\text { unframed log } \\
\text { and unframed } \\
\text { wooden box }\end{array}$ & $\begin{array}{c}\text { unframed } \\
\text { wooden box }\end{array}$ & - & $\begin{array}{c}\text { unframed log and } \\
\text { unframed wooden } \\
\text { box }\end{array}$ \\
\hline $\begin{array}{l}\text { Allow wild colonies moving } \\
\text { naturally to the urban area }\end{array}$ & $\begin{array}{c}\text { natural, } \\
\text { unframed } \\
\text { wooden box }\end{array}$ & $\begin{array}{c}\text { natural, } \\
\text { unframed } \\
\text { wooden box }\end{array}$ & $\begin{array}{l}\text { natural, artificial } \\
\text { palm cavities }\end{array}$ & - \\
\hline
\end{tabular}




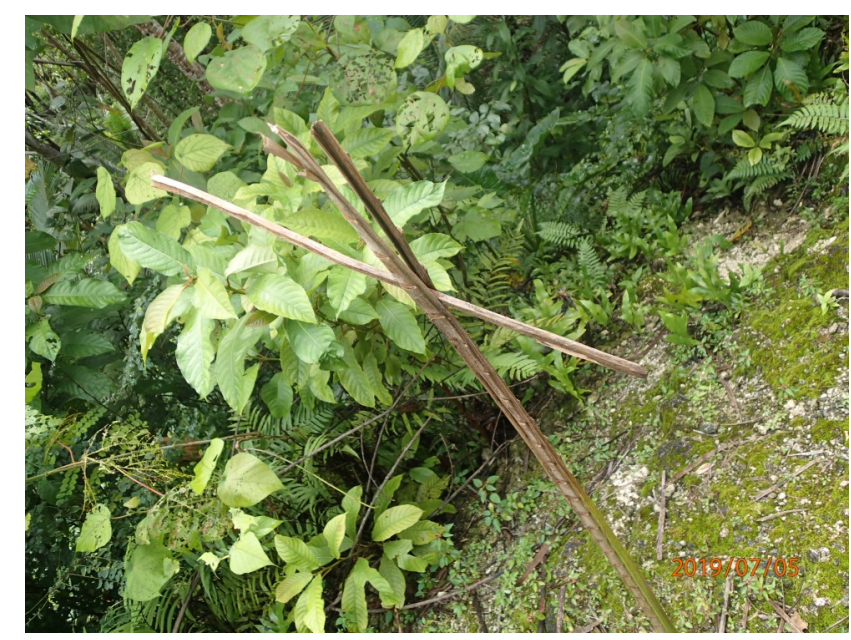

Figure 2. A sign to indicate ownership of the nest of the honey bee at Peleng Island.

Different from the practice of honey collecting of the giant honey bees (A. dorsata) that frequently involved praying or reading the bee mantra before the collection (Kahono unpublished data), the honey collecting at the observed locations did not involve such ceremonies. The honey collectors entering the forests brought a traditional smoker made from dry leaves covered by fresh leaves of shrubs or burned cigarettes to drive the honey bees not to become aggressive and to drive the bees away beside the combs. They used a parang knife that farmers usually use for the agricultural activity to cut the honeycombs. In the case of harvesting near the village, they deposited the combs in the baskets. However, they put the honey nests and brood nests in separate plastic bags when harvesting honey in the wild.

\section{The Traditional Honey Beekeeping}

The traditional honey beekeeping of $A$. cerana was conducted at Tasikmalaya, Bawean, and Kayan Hilir, beekeeping of A. koschevnikovi was only conducted at Kayan Hilir. Honey beekeeping was initiated by the collection of parental colonies from the forest or the wild inside the cavities of the living and the dead trees (Fig. 3), the limestones, and the underground. However, collecting of the parental colonies of both $A$. cerana and $A$. nigrocincta was not carried out at Peleng Island.

At the same time as the honey collecting at Tasikmalaya, Bawean Island, and Kayan Hilir, they also collected both the combs that contain broods and the parental colonies that contain a queen, many workers, and some drones. The combs were put in plastic buckets and the colony members were put into a wooden collecting box sized about 40x30x30 cm with a movable door side and a mosquito net for aeration (Fig. 4a). This box was useful for transferring the colony from the forest or the wild to the village or urban areas for honey beekeeping. 
These honey bee parental colony collections were also done by honey bee colony induction at Tasikmalaya, Kayan Hilir, and Bawean Island by putting unframed logs (Fig. 4b) or unframed wooden boxes in the forest or the wild and keeping them there for several weeks to attract wild swarming honey bee colonies. When the induction boxes had been occupied and the brood had been built, in order to avoid their large predators such as the forest mouse and Javan eagle, and especially the honey bear and orangutan in Kayan Hilir; the colonies were immediately transferred to surrounding villages or rural areas and kept in the traditional hives or unframed boxes in order to ease the maintenance and keep the colonies safe. After the honey was harvested, a few colonies were kept stay in the hives and most of them escaped to the wild. These traditional beekeeping activities follow the natural phenology patterns of different times and periods of mass flowering between the forest trees, the wild, and urban plants that have been practiced since ancestral time.

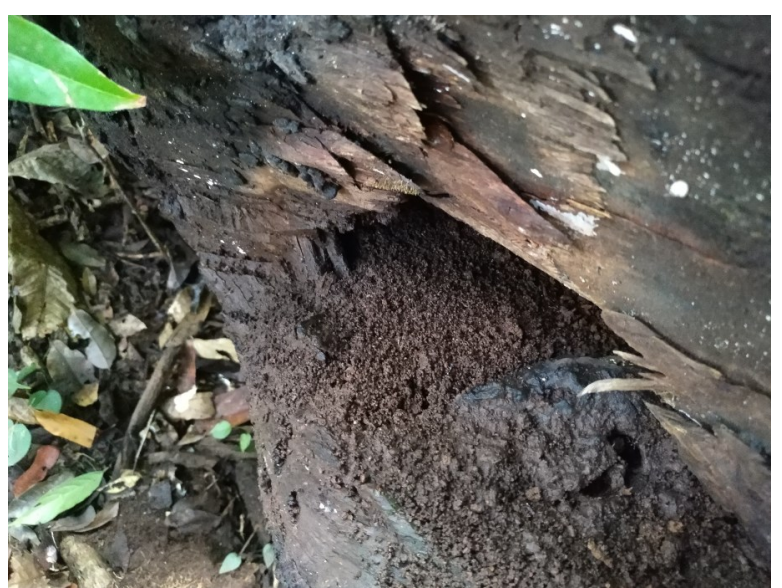

a

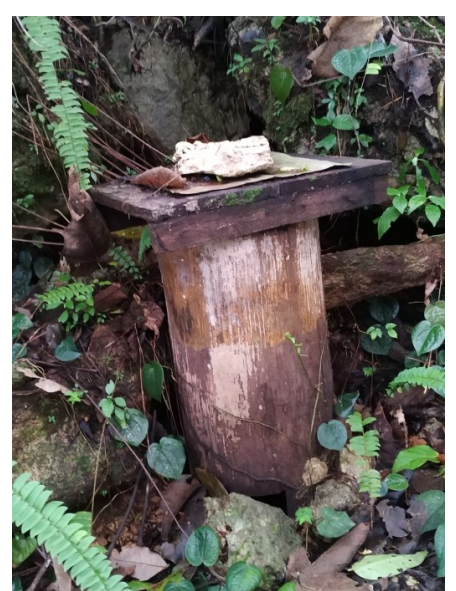

b

Figure 3. a. Honey bee colony inside dead trees; b. artificial nest cavities from cut Onchosperma palm trees.

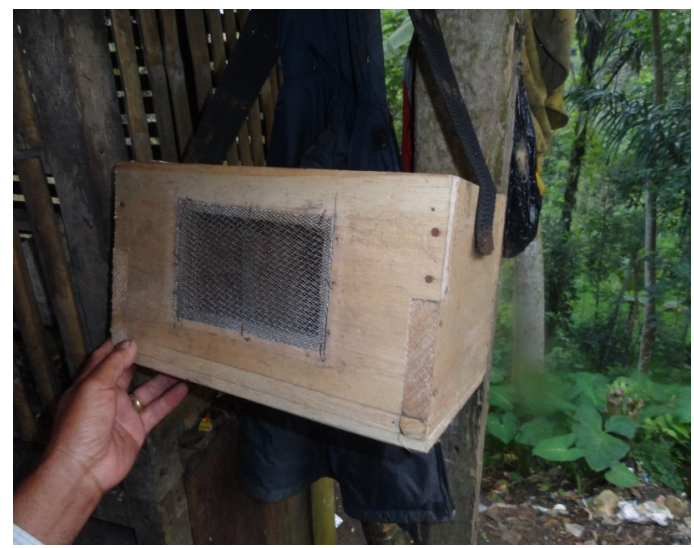

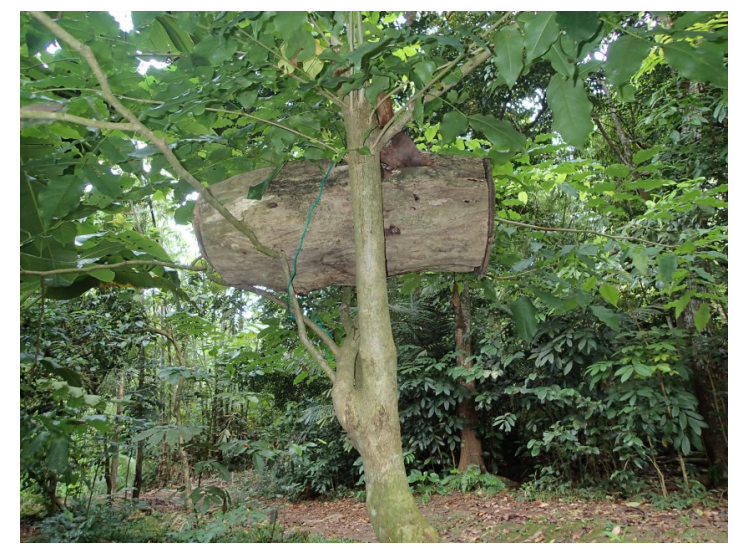

b

Figure 4. Traditional honey beekeeping: (a) with a wooden box to collect parental colony at Tasikmalaya; (b) colony induction by putting an unframed log. 
The honey production at all study sites was sold to local residents and even sometimes sold to local markets, while the broods were for the consumption of their own family. The honey production in Bawean Island and Peleng Island were also sold out to the mainland of Java and Sulawesi, respectively. Some Bawean people have also exported the honey to Malaysia. These activities have helped the family's health and income.

\section{DISCUSSION}

The identification guide to the Indonesian honey bees has been published (Ruttner, 1988; Otis, 1991; Engel, 2012), and their large islands' national distribution has been compiled (Hadisoesilo \& Kuntadi, 2007; Kahono et al., 2018). It is interesting to reveal the local wisdom of the ownership of the colonies. The ownership of close-nested honey bee colonies (A. cerana and A. nigrocincta) and of the giant honey bee (A. dorsata) in Peleng island is the temporary ownerships and it is the same as that of A. dorsata at the districts Nanga Lauk, Kapuas Hulu, Pontianak (Rosadi, 2020), at Malasari, district Nanggung, Kabupaten Bogor, West Java, and some other area in Sumatra (Kahono unpublished data). In many cases, the ownerships of sialang nesting trees of A. dorsata in Sumatra have become permanent ownerships.

The traditional beekeeping practices have been done in all study sites since ancestral times as local knowledge passed on to the descendants. These traditional activities follow the patterns of different times and periods of mass flowering between the forest and the wild trees and urban plants. The local honey collectors get used to their local knowledge of the time, the location, and the way to collect the honey. There are direct relationships between the existence of honey bees and the supporting environments (Winfree, 2010). Local people understand the major flowering season in the humid tropical country that generally starts from the end of the wet season until the middle of the dry season, as mentioned in Backer \& Brink (1963). Natural forest and artificial human-made habitats show various distinctions of the major flowering seasons. The distance among ecosystem types is an important factor for the honey bee colonies to move from unfavorable ecosystems to better ones.

There are differences in the range of migrating and swarming flights of different species (Solberg, 1985; Dyer \& Seely, 1994). The honey bee is a well-known seasonal migratory insect, A. dorsata is capable of long-distance migratory flight (Jack et al., 2019), however, the capability of the close-nested honey bee's movement is not so high compared to other bigger giant honey bees. The ecosystems surrounding the forest become important habitats to the migration of the honey bees (Winfree, 2010; Kahono, 2011; Kahono et al., 1999). Local people have followed the alternation of time periods or flowering dynamics between 
the forest trees and other wild plants alternating with plants in the rural environment. They believe that the honey bees adapt to those seasonal flowering patterns so that their movements instinctively follow the seasonal flowering patterns. The three species of honey bees seasonally move from forests to the rural areas and vice versa. During the flowering season of crops and other agricultural plants in the villages and rural areas, the bee colonies would come from the forest or the wild nearby, and vice versa from the forests or the wild to the villages or to the rural areas. The patterns of food resources dynamics between habitats over time require the ability of insects to move and adapt (Drake \& Gatehouse, 1995; Waldbauer, 1996). The honey collecting was conducted based on those seasonal flowering alterations between the forest and the villages.

The environmental changes have made the honey bees move seasonally to find a better environment. With that knowledge, local people developed their traditional knowledge on honey collecting and honey beekeeping based on seasonal environmental changes. The annual seasonal movement of the endemic species of close-nested honey bee $A$. nigrocincta and the introduced species of $A$. cerana among the forest and the rural areas at Peleng island has been well known by local people. The bees nested in the forest and moved to the rural area in a certain period and the cycle continued annually. Before the colonies emigrated to the rural areas and surrounding villages at the end of the year, the local people had prepared artificial nest cavities from cut Onchosperma palm trees (Fig. 3b) for the emigrant colonies. However, there was very few $A$. cerana because from the 18 new emigrated colonies to the rural areas, 16 colonies (88,9\%) were $A$. nigrocincta (Kahono et al., 2019).

The methods of the traditional honey beekeeping in the four study sites were strictly different from those in Turkey, India, Nigeria, and other countries (Onwumere \& Onwukwe, 2012; Yilmaz, 2016). The collection of the parental colonies was conducted in the middle or the end periods of flowering at the forest in which the honey and the full broods were also collected. Traditional beekeeping practices can be applied continuously mainly due to the stability of the environment (Kahono et al., 2019) and some other socio-cultural conditions of the local communities. Although modern hives can be easily carried to different places, in some conditions modern beekeeping fails to be applied. For example, many colonies with a modern frame of honey beekeeping of A cerana were introduced to Peleng Island and Tasikmalaya, but the keeping was not successful and the bees died or escaped to nature. Surprisingly A. cerana in Tasikmalaya and A. cerana and A. nigrocincta in Peleng Island conducted the same seasonal migration pattern that was also done by the giant honey bee $A$. dorsata binghami as reported by Nagir et al. (2016). Those honey bees' occupation dynamics were synchronized to the seasonal fluctuation of the flowering plants. 
The distance of migration and foraging territory of smaller honey bees, in this case, $A$. cerana and A. nigrocincta were shorter and narrower compared to those of the giant honey bee. The physiological and ecological factors of the variety of species are consistent concerning insect migration (Dingle, 1972). Seasonal mass colony migrations were performed by the giant honey bee A. dorsata (Koeniger \& Koeniger, 1980; Kahono et al., 1999). The mass seasonal migrations of close-nested honey bees $A$. cerana and $A$. nigrocincta in Peleng island and A. cerana at Tasikmalaya and Bawean Island were strongly triggered by the different phenology of both forests and urban habitats. The mass migration of the close-nested honey bees that were related to the seasonal flowering changes in Indonesia has not been reported before. The taste of honey in Peleng Island was different between the two close-nested species and $A$. dorsata binghami. The honey produced by $A$. cerana and A. nigrocincta were quite bitter compared to that of A. dorsata binghami. The differences in taste indicate that the nectar selected by the honey bees may come from different species of plants with different chemical compositions (Ball, 2007; Ajibola, 2015). To know the chemical composition, further biochemical research is necessary to be done.

Honey bees are important for honey production and also for the environment. About $90 \%$ of the world's plant species are pollinated by animals, and the primary animal pollinators in most ecosystems are bees (Bawa, 1990; Neff \& Simpson, 1993; Linder, 1998). Clearly, bees are the most important group for pollination in the forests, in the wild, and in agricultural ecosystems, thus knowledge about honey collecting and honey beekeeping needs to be documented.

\section{CONCLUSION}

The diversity of the closed-nested honey bees at the four study sites was A. cerana, A. koschevnikovi, and A. nigrocincta. The traditional honey collecting and honey beekeeping depend on the flowering periods. People at Peleng Island did not conduct honey beekeeping but collected honey directly from the forest.

\section{ACKNOWLEDGMENTS}

This research of traditional honey beekeeping was conducted as part of both the faunal exploration and science dissemination of the Research Centre for Biology, Indonesian Institute of Sciences (LIPI), for which we are grateful for the funding supports. We thank Mr. Labi Mapok (Kokolomboy), Mr. Nursamsi (Bawean Natural Reserved), and all who have assisted in the field. 


\section{REFERENCES}

Ajibola, A. 2015. Physico-chemical and physiological values of honey and its importance as a functional food. International Journal of Food and Nutritional Sciences, 2 (2): 180-188.

Ball, W.D. 2007. The chemical composition of honey. Journal of Chemical Education, 84(10): 16431646.

Bawa, K.S. 1990. Plant-pollinator interactions in tropical rain forests. Annual Review of Ecology Systematics, 21: 399-422.

Backer, C.A. \& Brink Jr., R.C.B.V.D. 1963. Flora of Java, vol. 1 (Spermatophytes only). The Netherlands: Groningen: NVP Noordhof.

Dingle, H. 1972. Migration strategies of insects. Science, 175 (4028): 1327-1335.

Drake, V.A. \& Gatehouse, A.G. 1995. Insect Migration. Tracking Resources through Space and Time. Cambridge University Press: 478 pp.

Dyer, F.C. \& Seely, T.D. 1994. Colony migration in the tropical honey bee Apis dorsata F. (Hymenoptera: Apidae). Insectes Sociaux, 41: 129-140.

Engel, M.S. 2012. The honey bees of Indonesia (Hymenoptera: Apidae). Treubia, 39: 41-49.

Gratzer, K., Susilo, F., Purnomo, D., Fiedler, S. \& Brodschneider, R. 2019. Challenges for beekeeping in Indonesia with autochthonous and introduced bees. Bee World, 96 (2).

Hadisoesilo, S. 1997. A comparative study of two species of cavity-nesting honey bees of Sulawesi. Dissertation. Canada: Guelph: University of Guelph.

Hadisoesilo, S. 2001. The diversity of indigenous honey bee species of Indonesia. Biodiversitas, 2 (1): 23-128 (translated).

Hadisoesilo, S. \& Kahono, S. 2011. The potential of forest honey bee Apis dorsata in Sumbawa Besar. Expedition Report of Indonesian Forest Honey Association (JMHI) (translated).

Hadisoesilo, S. \& Kuntadi, S. 2007. Local wisdom in beekeeping of a forest honeybee (Apis dorsata). Forest Department, Research and Development of Forestry, Center Research and Development for Forestry and Conservation (translated).

Hadisoesilo, S. \& Otis, G.W. 1996. Drone flight times confirm the species status of Apis nigrocincta Smith, 1861 to be a species distinct from Apis cerana F in Sulawesi, Indonesia. Apidologie, 27:361-369.

Hadisoesilo, S., Meixner, M. \& Rutter, F. 1999. Geographic variation within Apis koschevnikovi Buttel Reepen, 1906 in Borneo. Treubia, 31: 305-313.

Hamidi, U. 2001. Traditional wisdom of environmental management of the Melayu community of the province of Riau. In: Potential Environmental Wisdom. Office of the Indonesian Ministry of the Environment: pp. 706-711 (translated).

Jack, C.J., Lucky, A. \& Ellis, D.J. 2019. Giant Honey Bee Apis dorsata Fabricius (Insecta: Hymenoptera: Apidae). A series of the Entomology and Nematology Department, University of Florida/IFAS Extension. EENY646: 1-6.

Jamiat, Iskandar \& Idham, M. 2019. The Local wisdom of the community in preserving natural honey bees with tikung techniques in the ares of Siawan Belida, Nanga Tuan village, Bunut Hilir subdistrict, Kapuas Hulu regency. Jurnal Hutan Lestari, 7(2): 743-752 (translated).

Kahono, S. 2011. Effect of extreme wet climate on the number of immigrant colonies of the giant honeybee Apis dorsata F. International Conference on Conservation and Management of Pollinators. September 14-17, 2011, Kuching, Sarawak, Malaysia.

Kahono, S. 2018. Diversity and the potential of Indonesian native bees. International Conference of Asian Apicultural Asociation, 22-25 November 2018, Jakarta, Indonesia.

Kahono, S., Sulistyadi, E., Fefirenta, A.D. \& Sadili, A. 2019. Diversity of eusocial bees (Hymenoptera: Apidae) dan traditional beekeeping at Peleng island, Banggai Kepulauan, Central Sulawesi. National Seminar of Apiary. Gadjah Mada University, Yogyakarta, September 2019. 
Kahono, S., Nakamura, K. \& Amir, M. 1999. Seasonal migration and colony behavior of the tropical honey bee Apis dorsata F. (Hymenoptera: Apidae). Treubia, 31(3): 283-297.

Kahono, S., Chantawannakul, P. \& Engel, M.S. 2018. Social bees and current status of beekeeping in Indonesia. In: P. Chantawannakul, G. Williams \& P. Neumann, eds. Asian Beekeeping in the 21th Century. Springer: $287-306$.

Koeniger, N. \& Koeniger, G. 1980. Observations and experiments on migration and dance communication of Apis dorsata in Sri Lanka. Journal of Apicultural Research 19: 21-34.

Mashudi, Patra, K. \& Suwanda, O. 1998. Honeybee and Honey in Indonesia Year 2000. Pusat Apiari Pramuka, 268 pp. (translated).

Mikael, Hardiansyah, G. \& Iskandar. 2015. Local wisdom community on natural honey management of Tunggul Boyok village, Bonti district of Sanggau Regency. Jurnal Hutan Lestari, 3(1): 80-87 (translated).

Linder, H.P. 1998. Morphology and the evolution of wind pollination. In: S.J. Owens \& P.J. Rudall, eds. Reproductive Biology. U.K.: Richmond: Royal Botanic Gardens, Kew: pp. 123-135.

Naderifar, M., Goli, H. \& Ghaljaie, F. 2017. Snowball sampling: A purposeful method of sampling in qualitative research. Strides in Development of Medical Education, 14(3): e67670.

Nagir, M.T., Atmowidi, T. \& Kahono, S. 2016. The distribution and nest-site preference of Apis dorsata binghami at Maros forest, South Sulawesi. Journal of Insect Biodiversity, 4(23): 1-14.

Neff, J.L. \& Simpson, B.B. 1993. Bees, pollination systems, and plant diversity. In: J. LaSalle \& I.D. Gauld, eds. Hymenoptera and Biodiversity. U.K.: Wallingford: CAB International: pp. 143-167.

Onwumere, J. \& Onwukwe, F. 2012. Comparative analyses of modern and traditional beekeeping entrepreneurship in Abia State, Nigeria. Journal of Economics and Sustainable Development, 3 (13): 2222-2855.

Otis, G.W. 1991. A review of the diversity of species within Apis. In: D.R. Smith, ed. Diversity of the Genus Apis. Oxford: Westview Press \& IBH Publishing Co. Pvt. Ltd.: pp. 29-50.

Purba, J. 2001a. Environmental wisdom of the community of Melayu Siak Sri Indrapura. In: Potential Environmental Wisdom. Office of the Indonesian Ministry of the Environment: pp. 698 705 (translated).

Purba, J. 2001b. Knowledge of natural resource utilization in the Talang Mamay community of Riau Province. In: Potential Environmental Wisdom. Office of the Indonesian Ministry of the Environment: pp. 107-115 (translated).

Rosadi. 2020. Learning local wisdom of honeybees from Nanga Lauk Village. People Resources and Conservation Foundation (PRCF) Indonesia. http://prcfindonesia.org/belajar-kearifan-lokal-daridesa-nanga-lauk-soal-lebah-madu (translated).

Ruttner, F. 1988. Biogeography and Taxonomy of Honeybees. Berlin: Springer-Verlag: 284 pp.

Sharma, D., Abrol, D.P., Ahmad, H., Bandral, R.S. \& Ishar, A. 2014. Traditional Beekeeping in Jammu and Kashmir, India. World Beekeeping.

Solbreg, C. 1985. Insect migration strategies and population dynamics. In: M.A. Rankin, ed. Migration: Mechanisms and Adaptative Significance. Contribution in Marine Science, vol. 27 (suppl.). The University of Texas at Austin: Port Aransas: Marine Science Institute: pp. 641-662.

Waldbauer, G. 1996. Insects through the Seasons. Harvard University Press: 289 pp.

Winfree, R. 2010. The conservation and restoration of wild bees. Annals of the New York Academy of Sciences, 1195 (2010): 169-197.

Yilmaz, O. 2016. Traditional honey beekeeping in Turkey. Journal Veterinary Advances, 6(10): 1317 -1324. DOI: $10.5455 / j v a .196912310400001$ 